\title{
O POLÍTICO E O POLICIAL EM RICARDO PIGLIA
}

\author{
Keli Cristina Pacheco \\ Doutoranda em Literatura - UFSC
}

Resumo: Observando a trajetória de Ricardo Piglia desde seus primeiros artigos publicados na revista argentina Los Libros, vê-se que há uma grande coerência entre seus projetos políticos da juventude e a sua opção pelo modelo da literatura policial de vertente norte-americana. Tal modelo procura expor a não correspondência entre a verdade e a lei, entre o Estado e o sujeito que nele habita, contudo ainda há crença em um topos vindouro. Impossível não lembrar de um Piglia jovem, engajado ao partido maoísta, depositando suas utopias na literatura.

Palavras-chave: Ricardo Piglia; Romance Policial; Engajamento.

Résumé: En observant la trajectoire de Ricardo Piglia depuis ses premiers articles publiés dans la magazine argentin Los Libros, on peut voir qu'il y a une grande cohérence entre les projets politiques de sa jeunesse et son option pour le modèle de littérature policière américaine. Tel modèle nous montre la non-correspondance entre la verité et la loi, entre l'État et le sujet qui l'habite, toutefois il y a encore la croyance dans un topos qui viendra. Impossible de ne pas se rapeller d'un Piglia jeune, engagé dans le parti moíste, en train de verser ses utopies dans la littérature.

Mots-clés: Ricardo Piglia; Roman Policier; Engagement. 
A vanguarda é uma das ideologias espontâneas de todo o escritor. (A outra é o realismo). Ricardo Piglia, Notas sobre literatura em um diário

Para o escritor, a verdadeira responsabilidade é a de suportar a literatura como um engajamento fracassado, como um olhar mosaico sobre a Terra Prometida do real.

Roland Barthes, Escritores e escreventes

Quando se decide elaborar uma reflexão sobre o método crítico de Ricardo Piglia é interessante pensar sobre sua trajetória na revista literária Los Libros, na qual participou ativamente; e ainda sobre a Vanguarda Comunista, ou melhor, sobre seu posicionamento maoísta, que se evidenciou em grande parte de seus ensaios publicados na Los Libros, no fim da década de 60 até 1975, meses antes de se instaurar a ditadura na Argentina, consolidada através do golpe militar de março de 1976.

Tendo Ricardo Piglia como um dos fundadores, a revista Los Libros propunha inicialmente funcionar como uma alternativa em contraposição aos suplementos culturais dos jornais argentinos. Voltada à cultura de massas, a nova publicação baseava-se no estruturalismo que, com sua epistemologia de pretensão totalizante, possibilitou a crítica ao modelo impressionista presentes nos cadernos culturais da época, conforme esclarece Piglia em entrevista a Jorge Wolff (2001, anexo 1, p. 21). A Los Libros tinha a revista francesa La Quinzaine como modelo, que resenhava os livros franceses lançados nos últimos quinze dias, porém o periódico argentino divulgava resenhas sobre as publicações de cada mês. ${ }^{1}$

No primeiro ano da publicação, 1969, Piglia, que já havia lançado o livro de contos La invasión ${ }^{2}$, escreve um artigo sobre a narrativa Trampa 22, de Joseph Heller, cumprindo o papel de conhecedor de literatura norte-americana no periódico. Sobre este início, relata: "[...] la revista en ese momento era una revista, digamos, que no tenía una línea definida, era una revista mas bien para crear un clima de discusión". (WOLFF, op. cit., p. 21)

Pedir uma definição de linha da revista era, naquele momento, solicitar um engajamento político maior. Uma vez que Piglia, na época, era ligado a um grupo maoísta, o que significava, segundo o próprio, ter uma posição crítica contra o comunismo da União Soviética, de Cuba, e ainda ter a alternativa de possuir uma referência com outro tipo de comunismo, no caso o chinês, liderado por Máo Tsé-Tung. Tal posicionamento político o impede de se comprometer como editor, permanecendo inicialmente como colaborador, pelo menos até o momento em que a revista assumisse um lugar de maior comprometimento com seus ideais políticos.

Os maoístas, na Argentina, se dividiam em dois grupos: a Vanguarda Comunista, da qual Piglia fazia parte; e o Partido Comunista Revolucionário - PCR, do qual participavam Beatriz Sarlo e Carlos Altamirano, ambos editores da revista Los Libros, sendo o último um dos fundadores. Sarlo, por sua vez, somente participará mais tarde na revista, precisamente para contrabalançar com seu posicionamento católico e peronista, porém logo se filia ao grupo maoísta, nos indicando que não só Piglia, mas todo o grupo da Los Libros encerrarase no posicionamento stalinista-leninista radical (que crê no materialismo vulgar e no determinismo econômico) em que se inspira Máo Tsé-tung (2008).

Porém a mudança, aparentemente radical, no posicionamento de Beatriz Sarlo parece influenciar, mais tarde, no apoio a Isabel Perón por parte do PCR e, justamente, nesse momento, em 1975, Ricardo Piglia se afasta da revista ${ }^{3}$. Contudo, no tempo em que 
atuou, Jorge Wolff (2001, p. 141) comenta que suas intervenções foram "quantitativamente escassas mas ideologicamente decisivas para o desenho de seu perfil de etapa em etapa".

Desse modo, vale dizer que no seu segundo artigo na Los Libros, Piglia traça uma oposição binária entre a 'nova' literatura dos Estados Unidos, de um lado; de outro as vanguardas francesas e as experiências latino-americanas, sendo que é dado destaque a primeira, tecendo elogios, em detrimento das outras. ${ }^{4}$ Segundo Jorge Wolff, a vertente negra do romance policial norte-americano surge como uma resposta "eficaz por uma nova esquerda (algo precocemente envelhecida) para o debate sobre as possibilidades de uma literatura que fosse ao mesmo tempo aberta e de cunho social. Tendo um yanki filiado ao Partido Comunista, Dashiell Hammett, o melhor modelo". (WOLFF, op. cit., p. 145) ${ }^{5}$

Já no terceiro artigo, o escritor maoísta resenha sobre a narrativa Cosas Concretas, de David Viñas: "la novela no hace otra cosa que narrar la imposibilidad de hacer hablar a la práctica política con las palabras de la literatura". No entanto, Piglia parece não aceitar muito tal despolitização das letras, quando complementa: "el reverso del discurso clandestino, silencioso, de la práctica revolucionaria". (PIGLIA, dez. 1969, p. 3)

$\mathrm{O}$ vínculo entre arte e política aparece novamente em outro ensaio, publicado no segundo ano da revista, intitulado "Nueva narrativa norteamericana", em que, na segunda parte, tece elogios aos Black Panthers por possuírem uma perspectiva comunitária da prática política, aproximando-os dos revolucionários chineses. Sendo que os Panteras Negras, hoje em dia, não são reconhecidos como escritores, mas sim como líderes políticos revolucionários que usavam a escrita em prol de uma luta. (PIGLIA, set. 1970, p. 11-14) ${ }^{6}$

Na Los Libros n. 25, de março de 1972, é impresso o artigo intitulado Máo TseTung. Práctica estética y lucha de clases, em que Piglia resenha o livro Charlas en el foro de Yenan sobre arte y literatura, de Mao Tsé-tung, a partir das suas leituras de Bertold Brecht, quando este fora influenciado pelo socialismo chinês. O autor do artigo, desta forma, nos mostra que era evidentemente ligado a uma certa leitura da tradição socialista que via a arte como um instrumento de luta social. Brecht é ainda tema de sua última aparição, o ensaio Notas sobre Brecht é publicado na revista, junto à carta em que comunica sua saída ao 'comitê de direção'. Nessa despedida da Los Libros, Piglia (mar.abr. 1975, p. 9) persiste na noção da literatura como um campo material de luta de classes e esclarece o seu modo de vê-la:

El realismo brechtiano combina distintas técnicas e instrumentos de trabajo para producir un efecto de realidad. En este sentido para Brecht no es realista quien 'refleja' la realidad....sino quien es capaz de producir otra realidad. ('No soy realista, soy un materialista; escapo del realismo yendo hacia la realidad' decía Eisenstein con palabras que parecen de Brecht). Esta otra realidad es 'artificial', construida, tiene leyes propias y exhibe sus convenciones...?

Tal discurso é, de alguma forma, sustentado até hoje, conforme relata em entrevista à revista espanhola Lateral, de janeiro de 2001. Sobre sua leitura de Brecht e sobre o romance policial Dinheiro queimado, diz:

Me interesan mucho su prosa, sus relatos, sus piezas breves y también 
sus reflexiones, que son extraordinarias. Entre ellas, hay una muy sugerente: la idea de que hay una gestualidad y un uso del lenguaje que condensan sentidos sociales. Como si uno fuera extranjero y se moviera dentro de una realidad, percibiendo el funcionamiento de esa nueva sociedad desde afuera, solamente por el uso del lenguaje y de cierto tipo de posturas, de sistemas de organización de las redes sociales: cómo se saluda la gente, cómo se sienta, etcétera. Eso me ayudó mucho a darle al trabajo de Plata Quemada un sentido que no fuera solamente naturalista o costumbrista. ¿Cómo trabajar un mundo cerrado, cuyo lenguaje parece una lengua extranjera, sin hacer de esto una mera reconstrucción antropológica o una visión costumbrista del habla de ciertos sectores? Para Brecht, ahí se deben encerrar sentidos que hablen del conjunto de la sociedad y no solamente de ese sector. De inmediato surgieron dos o tres cuestiones que excedían el ámbito de la novela: la droga, la sexualidad y el dinero, que para mí serían signos nítidos de esto que se llama el gesto social. $^{8}$ (PIGLIA, 2005, grifo nosso)

O gênero policial americano cumpriria esse papel de aparentemente não possuir pretensões realistas, pois o real apareceria como alegoria ${ }^{9}$, porém, mesmo assim, não perderia seu caráter social, ou a eficiência de interferir no 'mundo social' - adquirida através do deslocamento/estranhamento, às vezes até negação, da realidade - o que significaria crer numa materialidade do romance ${ }^{10}$. E para Piglia: "o romance não expressa nenhuma sociedade senão como negação e contra a realidade. A literatura sempre é inatual, ela diz em outro lugar, fora de hora, a verdadeira história. No fundo, todos os romances acontecem no futuro. Se a política é a arte do possível, a arte do ponto final, então a literatura é sua antítese. Nada de atos, nem transações, a única verdade não é a realidade". (PIGLIA, 1991, grifo nosso) ${ }^{11}$ Todavia, de algum modo, há uma realidade, mesmo que afastada, negada ou contrariada, a ser 'ficcionalizada' e, então, 'atingida'. Daí nasce a utopia em Piglia, a crença em um topos vindouro, como veremos mais adiante. Porém antes é preciso entender melhor o gênero policial.

No mesmo período em que a revista Los Libros circula, Ricardo Piglia trabalha para a editora Tiempo Contemporâneo, dirigindo a coleção Série Negra que publica, na Argentina, 28 volumes do romance negro norte-americano, vertente que entra em oposição direta ao romance antigo de enigma, de origem inglesa, em que há um detetive que encabeça o esclarecimento dos fatos e desvenda os crimes. ${ }^{12}$ Nesse tipo de romance, segundo Gilles Deleuze, em artigo escrito no momento em que se festejava o número 1000 da Série Negra, ${ }^{13}$ publicado originalmente em janeiro de 1966, "a verdade era aí concebida de uma maneira bem filosófica, isto é, como produto do esforço e das operações do espírito". (DELEUZE, 2006, p. 111)

Sendo assim, a noção do policial de enigma se instala na gênese do relato clássico, na relação entre suspensão da verdade dos fatos e revelação do real, impondo ao funcionamento do discurso uma dada inocência metafísica. Deleuze e Guattari, segundo Foucault, mostraram que Édipo não é um segredo do inconsciente, mas sim uma forma ilusória de contenção do desejo, um uso do poder psicanalítico. E assim sendo, é um complexo ao nível coletivo que condiz com a tragédia da pesquisa da verdade, do real, com o universo do desvelamento ocidental do enigma. O que justamente tem a ver com o gênero 
policial. Em Édipo, articula-se o jogo dos dois lados: o corpo assassinado, por um lado; o nome do assassino, por outro. É preciso a figura do sujeito-detetive (o próprio Édipo) para perscrutar e esclarecer o nome próprio do assassino, uma vez que "não se pode forçar a vontade dos deuses", como bem diz Foucault. Tal como nos ensina Link a respeito do romance policial, para a leitura foucaultiana de Édipo-Rei, em $A$ verdade e as formas jurídicas, o que está em jogo é o poder, seus regimes de aparição, e não a inocência ou a culpa de Édipo. Não interessa porque, em suma, efetua-se o assassinato, pois este se dá por ordem do "puro desejo da morte", as pistas criminais interessam no sentido que produzem o jogo infinito do relato policial, e não na lógica da possível desculpabilização moral do assassino. ${ }^{15}$

Ou seja, a verdade possui um elo com as ações, o universo da trama que o relato condensa na qualidade de discurso textual. Já no romance negro, ao contrário, a explicação, quando dada pelo 'detetive' ao fim da história não é a mais plausível, nem se destina a ser. A verdade policial não se dá essencialmente "como efeito do trabalho da enunciação discursiva". Resumidamente, como descreve Daniel Link (2002, p. 75-76), podemos ver que a lei, no policial, é entendida em dois pólos: o romance inglês, Borges, posições mais formalistas, por um lado; e o romance negro norte-americano, o Walsh, posições mais substancialistas.

O policial extrapola as balizas literárias, o caso e a crônica policial precedem o gênero policial ${ }^{16}$. Como é uma categoria abrangente que, como diz Link, está na relação social e histórica do Estado com o imaginário do caso criminal. Mais do que isso, está na relação do nomos e da verdade e seus regimes próprios de efetuação e aparição, o que caracterizaria uma das razões do interesse transcultural pelo tópico policial. Link destaca outra razão, ainda, a que chama de razão estrutural e que está no sentido de que o policial é "um modelo de funcionamento de todo relato: articular de maneira espetacular as categorias de conflito e enigma sem as quais nenhum relato é possível". ${ }^{17}$

A perspectiva do romance negro, que interessa mais nesse momento, pretende mostrar que não existe uma verdade final indiscutível, inquestionável, uma interpretação acima de qualquer suspeita - como vemos em Nome Falso, A cidade ausente, Dinheiro Queimado e ainda em algumas narrativas presentes em Formas Breves, em que o detetive e o criminoso são indecidíveis. ${ }^{18}$ Segundo Deleuze (2006, p. 112-113), o romance negro fora o primeiro a nos dizer que a atividade policial nada tinha a ver com

uma investigação metafísica ou científica da verdade. [...] A Série Noire nos habituou ao tipo do policial que arremete completamente ao acaso, mesmo correndo o risco de multiplicar os erros, mas acreditando sempre que daí sairá alguma coisa. [...] E, inocente, o leitor acaba se espantando com tantos erros de um lado e de outro. Até a polícia, quando prepara um golpe sujo, o faz tão desajeitadamente que parece debochar da opinião alheia.

Por outro lado, concebe-se que a sociedade está fundamentada no delito, uma vez que o crime é um pressuposto social, encontra-se, portanto, disseminado, pois participa e ao mesmo tempo é solicitado pela 'sociedade capitalista'. Deste modo, "o elemento social aparece enquanto 'massa', ao passo que a subjetividade se constituiria em forma de 
transgressão". (WOLFF, op. cit., p. 148)

Tal como uma peça de Brecht que termina com uma espécie de "Procurem a saída" (BARTHES, 1999, p. 168), a intenção é fazer com que o leitor se coloque como detetive, como o próprio Piglia esclarece em entrevista sobre Nome falso: "no meu texto há um enigma para o leitor, que explica toda a história e todos os dados estão ali, à espera do leitor-detetive". (PIGLIA, mar. 1989, p. 133) Para Piglia, esse lugar é o da transgressão, ao fazer o leitor-detetive penetrar nas minúcias do mundo do crime, ele perceberia as contradições, ambigüidades, dos jogos duplos do 'mundo em que vivemos'. Vê-se que, como na tragédia grega, há também no romance negro, não só no policial de enigma, um processo de restituição, de equilíbrio, mas dessa vez mais próximo à tragédia de Ésquilo (DELEUZE, op. cit., p. 113). Todavia, toda a poesia trágica, portanto, o romance negro e de enigma, segundo Walter Benjamin (1984, p. 129-130, grifo nosso),

se baseia na idéia de sacrifício. Mas o sacrifício trágico difere em seu objeto - o herói - de qualquer outro, e é ao mesmo tempo um sacrifício inaugural e terminal. Terminal, porque é uma expiação devida aos deuses, guardiães de um antigo direito; inaugural, porque é uma ação que anuncia novos conteúdos da vida popular, e em nome dela é praticada. Esses conteúdos, que ao contrário das velhas obrigações não emanam de um decreto superior, mas da própria vida do herói, o destroem, porque são desproporcionais à vontade do indivíduo, e só convém a uma comunidade popular ainda virtual. A morte trágica tem um sentido duplo: anular o velho direito dos deuses olímpicos, e sacrificar o herói, precursor de uma humanidade futura, ao deus desconhecido.

Assim sendo, nas suas narrativas, o detetive, o sujeito civil Ricardo Emílio Piglia $R e n z i{ }^{19}$ pretende, do seu modo, esclarecer a 'massa' quando a chama para preencher os vazios, na pretensão de fazê-la 'desvendar' o mundo que a cerca, cumprindo o papel daquele que se sacrifica em nome da comunidade. ${ }^{20}$

Sobre o efeito de verdade na narrativa policial, Raúl Antelo (1994, p. 28) enfatiza que este é induzido "por meio dos discursos ficcionais de modo que a partir de uma verdade realmente existente se ficcionaliza a própria história a ponto de transformá-la em realidade virtual. A verdade recorta-se, então, como versão ou tradução e se define como uma leitura utópica". ${ }^{21}$ Como indica Ricardo Piglia (2004, p. 57), no capítulo Os sujeitos trágicos (literatura e psicanálise) de Formas breves, quando se propõe, num momento, pensar a relação entre psicanálise e literatura através do gênero policial:

Hoje encaramos o mundo com base nesse gênero, hoje vemos a realidade sob a forma do crime, como dizia Bertold Brecht. A relação entre a lei e a verdade é constitutiva do gênero, que é bastante popular, como era a tragédia. A exemplo dos grandes gêneros literários, o policial foi capaz de discutir o mesmo que discute a sociedade, mas em outro registro. É isto o que faz a literatura: discute a mesma coisa de outra maneira. O que é um delito, o que é um criminoso, o que é a lei? Discute o mesmo que discute a sociedade, mas de outra maneira. 
Para o escritor essa seria a "chave de tudo", expor a não correspondência entre a verdade e a lei, entre o Estado e o sujeito que nele habita. O leitor-detetive, aquele que está fora da ficção pigliana, é aquele que está destinado a interpretar algo que aconteceu, a estabelecer um vínculo entre os dois elementos, e "vai dizer a verdade, vai descobrir a verdade que é visível, mas que ninguém viu, e vai denunciá-la" (id., p. 58). Tal percurso não é vão, pretende desembocar em algum lugar por vir, ou em uma comunidade por vir, como vimos com Benjamin. Esse lugar seria constitutivo da literatura argentina, pois com o real insatisfatório, dar-se-ia lugar a tentativa de construção de um espaço de fuga e salvação, como declara em entrevista. ${ }^{22}$ A tal utopia está imbricada a crença na acumulação e, ao mesmo tempo, uma descrença na inoperância do Estado, ou seja, na ficção pigliana ainda há uma teologia política. ${ }^{23}$

No entanto, "a literatura nunca pode explicar o mundo", escreve Roland Barthes (op. cit., p. 33) já em 1966, pois a linguagem, matéria da literatura, tem como fim neutralizar o verdadeiro e o falso. Quando a ela é atribuída uma função, torna-se uma espécie de linguagem segunda, pois se reveste de um sentido parasita. Daí a literatura somente poderá "conotar o real, não denotá-lo: o logos aparece irremediavelmente cortado da práxis; impotente para realizar a linguagem, isto é, ultrapassá-la em direção a uma transformação do real.”(BARTHES, op. cit., p. 172) Ao contrário do discurso que pretende produzir a "verdade" - a literatura "é o exílio da verdade", nos diz Maurice Blanchot (1987, p. 241), em 1955, pois nela reina a dissimulação. Uma vez que o espaço da ficção é aquele que torna possível o impossível, e impossibilita o possível quando "afirma a presença insólita das coisas reais em pura ficção, em pura ausência" (ibid., p. 38). Segundo Foucault (2001b, p. 225), num artigo publicado no mesmo ano daquele de Barthes, "o fictício não está nunca nas coisas nem nos homens, mas na impossível verossimilhança do que está entre eles: encontros, proximidade do mais longínquo, absoluta dissimulação lá onde nós estamos. A ficção consiste, portanto, não em mostrar o invisível, mas em mostrar o quanto é invisível a invisibilidade do visível". Ou seja, é um discurso no qual se acredita sem acreditar, como indica Deleuze, ao comentar sobre a verdade no romance negro.

É porque a verdade não é de modo algum o elemento do inquérito: não se pode nem sequer pensar que a compensação dos erros tenha como objetivo final a descoberta da verdade. Ao contrário, essa compensação tem sua dimensão própria, sua suficiência, uma espécie de equilíbrio ou de restabelecimento do equilíbrio, um processo de restituição que permite a uma sociedade, nos limites do cinismo, esconder o que ela quer esconder, mostrar o que ela quer mostrar, negar a evidência e proclamar o inverossímel. O assassino não encontrado pela polícia pode acabar morto pelos seus em nome dos erros que cometeu, e a polícia pode sacrificar os seus por outros erros, e eis que essas compensações não tem outro objeto a não ser a perpetuação de um equilíbrio que representa a sociedade inteira na sua mais alta potência do falso. (DELEUZE, op. cit., p. 113, grifo do autor)

Há uma frustração inerente na 'busca pela verdade', que só leva a uma perpetuação do que Deleuze lucidamente denomina 'elevada potência do falso', já que aquela mesma verdade, a que pretensamente poderia 'alcançar' o leitor, se dá somente como mais uma hipótese dentre tantas outras, infinitas, como indica Antelo: "A leitura verdadeira nada mais 
é do que uma hipótese (literalmente, uma suposição ou superposição de versões) que permite ler, de forma transversal, efeitos de poder encerrados ou cifrados como efeitos de verdade". Da ficção só poderia derivar a verdade como desencantamento do real, o que acarreta, como ainda escreve Antelo (op. cit., p. 28-29), uma atribuição de densidade alegórica "que inverte o determinismo referencial para a partir das causas mínimas produzir efeitos decisivos [...]. Muito mais do que uma proposição verdadeira (uma escritura), a verdade ficcional é uma estrutura histórica (uma interpretação)".

Daí entende-se a desvinculação da verdade com o real, que afasta a visão materialista, ou 'engajada' do romance policial negro, uma vez que a verdade está ligada, de fato, ao processo psicanalítico, como anuncia Link (op. cit., p. 81):

A teoria da verdade de policial definitivamente não é materialista, mas psicanalítica, como muito bem suspeitou Lacan. Em "A carta roubada" há um delito propriamente político. Sua resolução, no entanto, é inteiramente alheia à política. A famosa carta, de cujo conteúdo quase nada sabemos, é recuperada com o aspecto de uma carta de amor e somente nos é concedido o direito de entender esta carta enquanto parte desse gênero. A política é transformada em paixão: este processo é constante no policial.

Tal ponto de vista instaura a percepção de que a verdade da ficção não tem nenhuma ligação com o real, e sim com outras ficções. Nos aproximamos aqui do método psicanalítico, proposto por Jacques Lacan no seminário $O$ estádio do espelho como formador da função do eu tal como nos é revelada na experiência psicanalítica, em que Lacan aponta para a queda das identificações imaginárias que procuram abrigar com sentido o vazio, a fissura ontológica, que é o sujeito. Desta forma, podemos dizer que as imagens, que alienam o sujeito, cristalizam-no na ficção de ter uma unidade substancial que o faz permanecer, no tempo, idêntico a si mesmo. Assim justamente o que produz a queda das identificações imaginárias levadas até o limite estático de "tu és isto, tu és nada", é um efeito de verdade. Esta verdade, que introduz o fim da análise, lhe revela que o seu ser é nada. Que qualquer tentativa de se afirmar eternamente numa imagem que o defina é uma ficção que o defende do vazio do seu $\operatorname{ser}^{24}$. (LACAN, 1998, p. 96-103)

O real de Piglia, caso sofresse um processo psicanalítico, se desestabilizaria, uma vez que ele próprio se veria como ficção. E o detetive-leitor, indignado, buscaria a origem de sua revolta...Será que ela surge em conseqüência do real, ou graças a uma ficção? Deleuze (op. cit., p. 115) ao seu modo, a tal pergunta, responderia:

Portanto, a Série Noire transformou nossas avaliações, nossos devaneios policiais. Tinha chegado o momento. Foi bom que participássemos na "leitura corrente" desse estado de coisas, que perdia por isso mesmo um pouco de sua realidade e nos roubava certa potência de indignação? A indignação surge graças ao real ou graças as grandes obras. Parece que a Série Noire copiou cada grande escritor romancista: um falso Faulkner, mas também um falso Steinbeck, um falso Caldwell, um falso Asturias. [...] É evidente que um realismo novo não basta para fazer boa literatura. O real enquanto tal é, para a má literatura, objeto de estereotipias, de 
puerelismos, de sonhos baratos, muito mais do que uma imaginação imbecil seria capaz de fazer. Porém, mais profundo do que o real e o imaginário, é a paródia. [...] A paródia é a categoria que ultrapassa o real e o imaginário.

1 A revista nasce no momento em que a Argentina vivia o entremeio político dramático pré-ditatorial, sabidamente, um ano antes, em 1968, a França passava por uma revolução política e intelectual, tendo a revolta pela independência da Argélia e a filosofia engajada de Jean Paul Sartre como marcas. Em $O$ que é a literatura?, Jean Paul Sartre procura responder a questão a partir de uma vinculação entre a literatura e o "mundo social", influenciado por pensamentos marxistas. Sobre isto, Roland Barthes comenta rapidamente, no ensaio Literatura e Metalinguagem, que Sartre buscou responder a pergunta do exterior, o que lhe deu uma posição literária ambígua. (Cf. BARTHES, 1999, p. 28)

${ }^{2}$ Em 1968, um ano depois do lançamento de La invasión, Piglia publicara duas antologias: Yo e Crónicas de Latinoamérica, porém estas não serão pontuadas, já que nosso breve estudo se deterá na questão da postura do escritor frente à ficção, se esta se dá como mimese do 'real' ou não.

${ }^{3}$ Em nota, Jorge H. Wolff (2001, p. 143) escreve: “o antinacionalismo de Sarlo e Altamirano se faz ambíguo e pouco convincente quando, em 1975, decidem apoiar o governo de Isabel Perón, como se verá, o que provoca a ruptura com Piglia e de algum modo reinventa o passado peronista de Sarlo".

${ }^{4}$ A crítica à febre latino-americana do realismo fantástico aparece neste artigo através do nome de Garcia Márquez. Contudo, segundo Raúl Antelo, "a crônica, o fantástico e a narrativa de suspense revelam posições preferenciais do discurso de verdade para a modernidade de 1900”. Tanto o fantástico como o policial partem de uma pretensa 'realidade', ficcionalizam-na e, por fim, elevam-na a uma posição utópica. (ANTELO, in FABRIS, 1994, p. 28)

${ }^{5}$ Conhecido como criador do romance negro, Dashiell Hammett começou a publicar seus contos, em 1925, na revista Black Mask, um periódico barato e com baixa qualidade de impressão, porém, em 1945, sai na França a Série Noire, quando se dá enfim o reconhecimento do público.

${ }^{6}$ A luta dos Panteras Negras pode ser vista como um momento essencializante, fraco, pois naturaliza e deshistoriciza a diferença, "confunde o que é histórico e cultural com o que é natural, biológico e genético. No momento em que o significante 'negro' é arrancado de seu encaixe histórico, cultural e político, e é alojado em uma categoria racial biologicamente construída, valorizamos, pela inversão,a própria base do racismo que estamos tentando desconstruir". (Cf. HALL, 2003, p. 345)

${ }^{7}$ Um ano depois a Los Libros encerra, visto que a ditadura se instaura na Argentina, mas mesmo nestas condições, não só de regime político, como também de falta de 'empatia' política, Piglia une-se novamente a Sarlo e Altamirano para fundar então a Punto de Vista. Contudo, esta tem a direção eliminada pelos militares.

${ }^{8}$ Não em vão a narrativa Dinheiro Queimado inicia com uma citação de Brecht. Piglia retoma as "cinco dificuldades para escrever a verdade": o valor de escrevê-la; a perspicácia para reconhecê-la; a arte de convertê-la em arma; inteligência para escolher o destinatário; e grande astúcia para difundi-la. (Cf. PIGLIA, 1998, p. 5)

${ }^{9}$ Piglia utiliza a técnica do distanciamento de Brecht, o que, no fim, faz do real uma alegoria, "Para mí también era importante manejar la óptica Henry James en relación con el distanciamiento de Brecht. El distanciamiento, diría Henry James, es móvil: la distancia no es siempre la misma, pero siempre existe. Uno tiene que encontrar un movimiento que le permita acercarse y luego alejarse, estar adentro y luego afuera. Por momentos, narra alguien que no sabe lo que está pasando; por momentos, alguien que conoce toda la historia. La hipótesis del distanciamiento es importante, porque implica mirar la vida cotidiana como si la viéramos por primera vez. El distanciamiento es desfamiliarización. El arte es extrañamiento: una manera nueva de mirar lo que ya vimos. En cuanto a estilo, había que trabajar con una lengua que no arrastrara los clichés de lo que suponemos estilo literario. Es decir, construir un estilo que surgiera de la propia masa verbal y de la anécdota." (PIGLIA, 2005)

${ }^{10}$ Isso significa admitir que há relações entre o âmbito cultural e o político-econômico e nesta postura está imbricada à negação da visão clássica de admitir o econômico como determinante (tese central de Marx). Hall nos ensina que a primeira tentativa de negar a determinação do econômico foi postulada por Althusser, já que ele chegou à conclusão de que o cultural/ideológico, o político e o econômico são sobredeterminantes. 
Contudo Althusser não conseguiu desvencilhar-se do pressuposto marxista clássico, uma vez que ainda acredita que "em última instância" é o econômico que determina. Gramsci seria então o nome que resolveria este nó teórico, já que ele, segundo Hall, "tinha plena consciência do quanto as linhas divisórias ditadas pelos relacionamentos de classe eram perpassadas pelas diferenças regionais, culturais e nacionais; também pelas diferenças nos compassos do desenvolvimento regional ou nacional". (HALL, 2003, p. 301)

${ }^{11}$ Contudo, o escritor parece se afastar, em Dinheiro queimado, da técnica de distanciamento brechtiano que até então havia utilizado, como declara: “[...] o que acontece é que aqui [refere-se à narrativa Dinheiro Queimado] essa indecisão entre ficção e realidade é trabalhada de outra forma. Não se trata de produzir um efeito ficcional, mas sim de produzir um efeito de realidade". (PIGLIA, 1999, p. 60)

12 "Se existe verdade (e não importa de que ordem é essa verdade), deve haver alguém encarregado de compreendê-la e revelá-la ao leitor. É o caso do detetive, um elemento estrutural inevitável na constituição do gênero. $\mathrm{O}$ detetive, como assinala Lacan, é o que vê o que está aí mas ninguém vê: o detetive, pode-se dizer, é quem investe de sentido a realidade brutal dos fatos, transformando em indícios as coisas, correlacionando informação que, isolada, carece de valor, estabelecendo séries e ordens de significados que organiza em campos: como Lacan não leria aí a presença do psicanalista? Como Eco e Sebeok não leriam aí o semiólogo?" (LINK, 2002, p. 74-75)

${ }^{13} \mathrm{O}$ presente trabalho foi escrito, numa primeira versão, para a disciplina "A imanência textual. Arqueologia do literário e teorias da diferença", ministrada pelo professor doutor Raúl Antelo, no ano de 2005. Aproveito para agradecer ao professor pelo empréstimo da Arts e Loisirs com o artigo "Le numéro 1000 - Philosophie de la Série Noire", de Gilles Deleuze, que na época não se encontrava traduzido.

${ }^{14}$ Segundo Deleuze, nessa vertente ainda havia duas escolas da verdade: a francesa cartesiana, onde a verdade está ligada a uma intuição intelectual básica, da qual é necessário deduzir o resto com rigor; e a escola inglesa (Hobbes), de acordo com a qual a verdade é induzida de outra coisa, interpretada a partir de sinais. De um lado temos a linha inglesa: Conan Doyle, com Sherlock Holmes, gênio indutivo; e a francesa: Gaboriau, com Tabaret e Lecoq, seguidamente com Gaston Leroux, com Rouletabille, dedutivos. A verdade só há no sentido de que é matéria prima que alguém omite e revela, o que salienta a figura e o papel do sujeito-detetive, como responsabilidade parapolicial da verdade, da fuga do obscuro do significado (através da liberdade de valores substanciais e marginais de sua consciência singular).

${ }^{15}$ A lição de Foucault é de que a personagem Édipo chega ao verdadeiro assassino por olhar demais, e não por ingenuidade. E a marca do ocidente até Nietzsche será precisamente a disjunção entre saber e poder, a idéia da cegueira do poder."O Ocidente vai ser dominado pelo grande mito de que a verdade nunca pertence ao poder político, de que o poder político é cego, de que o verdadeiro saber é o que se possui quando se está em contacto com os deuses ou nos recordamos das coisas, quando olhamos o grande sol eterno ou abrimos os olhos para o que se passou. Com Platão, se inicia um grande mito ocidental: o de que há antinomia entre saber e poder. Se há o saber, é preciso que ele renuncie ao poder. Onde se encontra saber e ciência em sua verdade pura, não pode mais haver poder político. Esse grande mito precisa ser liquidado. Foi esse mito que Nietzsche começou a demolir ao mostrar, em numerosos textos já citados, que por trás de todo saber, de todo conhecimento, o que está em jogo é uma luta de poder. O poder político não está ausente do saber, ele é tramado com o saber". (FOUCAULT, 2001a, p. 50-51)

${ }^{16}$ Lembremos que em a Microfisica do Poder, numa entrevista à Magazine Littéraire, Foucault contextualizará historicamente a intensificação e o nascimento moderno da literatura policial e das narrativas de crimes. "Mas eu me pergunto se o trabalho penal não foi organizado precisamente para produzir entre os delinqüentes e os operários este desentendimento tão importante para o funcionamento geral do sistema. $\mathrm{O}$ que temia a burguesia era esta espécie de ilegalismo sorridente e tolerado que se conhecia no século XVIII. Não é preciso exagerar: os castigos do século XVIII eram de grande selvageria. Mas não é menos verdadeiro que os criminosos, pelo menos alguns dentre eles, eram tolerados pela população. Não havia uma classe autônoma de delinqüentes. Alguém como Mandrin era recebido pela burguesia, pela aristocracia, bem como pelo campesinato, pelos lugares em que passava, sendo protegido por todos. A partir do momento em que a capitalização pôs nas mãos da classe popular uma riqueza investida em matérias-primas, máquinas e instrumentos, foi absolutamente necessário proteger esta riqueza. Já que a sociedade industrial exige que a riqueza esteja diretamente nas mãos não daqueles que a possuem mas daqueles que permitem a extração do lucro fazendo-a trabalhar, como proteger esta riqueza? Evidentemente por uma moral rigorosa: daí esta 
formidável ofensiva de moralização que incidiu sobre a população do século XIX. Veja as formidáveis campanhas de cristianização junto aos operários que tiveram lugar nesta época. Foi absolutamente necessário constituir o povo como um sujeito moral, portanto separando-o da delinqüencia, portanto separando nitidamente o grupo de delinqüentes, mostrando-os como perigosos não apenas para os ricos, mas também para os pobres, mostrando-os carregados de todos os vícios e responsáveis pelos maiores perigos. Donde o nascimento da literatura policial e da importância, nos jornais, das páginas policiais, das horríveis narrativas de crimes.". (FOUCAULT, 1999, p. 132-133)

${ }^{17}$ Para Daniel Link (op. cit., p. 73), "a literatura policial instaura uma paranóia de sentido que caracteriza nossa época". A morte, no policial, se põe para Link como "puro desejo da morte". Não há razões para o assassinato, além da pura obsessão que deixa pistas ao universo do relato, o universo da investigação sem fim, investigação entre o conflito e o enigma.

${ }^{18}$ Em Nome falso, o narrador-detetive pode também ser visto como criminoso quando publica a suposta narrativa de Roberto Arlt no livro que traz sua assinatura na capa, assemelhando-se a personagem Kostia, que antes publicara a narrativa assinando como se fosse sua. Em A cidade ausente, lançada em 1992, o leitor é convocado a se identificar com a personagem Junior e a desconfiar do que lhe é narrado. Em Dinheiro queimado, 1997, baseado numa história real, temos um narrador pouco confiável que trabalha com "pedaços de vida", contando a história de um assalto à banco realizado por Gaucho e Nenê, personagens envolvidas com políticos, policiais e com o crime, e ao fim é solicitado ao leitor que complete a verdade, extraída de retalhos, rumores e recortes de jornais.

${ }^{19}$ Emílio Renzi é uma espécie de alter-ego de Ricardo Piglia, notadamente em Formas breves, e também é o narrador-detetive de Respiração artificial, Prisão perpétua e Cidade ausente. Em Nome falso, parece ser o próprio Piglia o narrador-detetive, apesar de nunca ser citado em diálogo o nome do narrador.

${ }^{20}$ O sacrifício do detetive, para Piglia $(2004$, p. 58), se dá quando ele se põe fora do universo que analisa: Ele "não pertence ao mundo do delito nem ao mundo da lei, não é um policial e tampouco um criminoso [...]. E ao mesmo tempo o detetive é o verdadeiro intelectual, mostrando que a verdade já não está nas mãos dos sujeitos puros do pensar, mas deve ser construída em situação de perigo, função que passa a encarnar".

${ }^{21}$ Como também aponta Barthes: "Mas desde o momento em que se pensa que a sociedade não pode desalienar-se fora de um processo político ou, mais largamente, histórico, essa mesma coincidência (ou reconciliação), sem deixar de ser crível, passa para o plano da utopia; existe pois, desde então, uma visão utópica (e mediata) e uma visão realista (e imediata) da literatura; essas duas visões não são contraditórias, mas complementares". (BARTHES, op. cit., p. 73)

22 "Eu acho, então, que estamos na presença de um imaginário constitutivo da literatura argentina, a insatisfação relativa à realidade tal como ela é e a correlata construção de um espaço de fuga e salvação, de um lugar onde está aquilo que se deseja e que, ao mesmo tempo, é um lugar de perigo". (PIGLIA, mar. 1989, p. 133)

${ }^{23}$ Concordamos com Wolff (op. cit., p. 153): "Tal visão social da arte surge, portanto, carregada de populismo, um 'populismo de vanguarda': o povo, o leitor e o escritor do grande texto comum, apoiado pelos intelectuais orgânicos, vai subverter as relações de produção capitalistas, que asseguram ao autor a propriedade privada do sentido".

${ }^{24}$ É interessante acrescentar que ao fim de Os sujeitos trágicos (literatura e psicanálise), Piglia conclui que a função do detetive se aproxima a do psicanalista, pois ambos cumprem um percurso de interpretação, no entanto, como veremos, seria interessante que o detetive-leitor de Piglia também fosse também alvo de um processo psicanalítico.

\section{REFERÊNCIAS}

ANTELO, Raúl. Fábulas da integração falha. In: FABRIS, Annateresa (org.) Modernismo e modernidade no Brasil. São Paulo: Mercado das Letras, 1994. (Coleção “Arte: Ensaios e Documentos") 
BARTHES, Roland. Crítica e verdade. Trad. Leyla Perrone-Moisés. 3. ed. São Paulo: Perspectiva, 1999. (Série "Debates")

BENJAMIN, Walter. Origem do drama barroco alemão. Trad. Sérgio Paulo Rouanet. São Paulo: Brasiliense, 1984.

BLANCHOT, Maurice. O espaço literário. Trad. Álvaro Cabral. Rio de Janeiro: Rocco, 1987.

DELEUZE, Gilles. Filosofia da Série Noire. In: . A Ilha Deserta e outros textos. São Paulo: Iluminuras, 2006.

FOUCAULT, Michel. Microfisica do poder. Trad. Roberto Machado. 14. ed. Rio de Janeiro: Graal, 1999.

- A verdade e as formas jurídicas. Trad. Roberto Cabral de Melo Machado e Eduardo Jardim Morais. 2. ed. Rio de Janeiro: Nau, 2001a.

. Por trás da fábula. In: . Ditos e escritos 3: Estética: Literatura e Pintura, Música e Cinema. Trad. Inês Autran Dourado. Rio de Janeiro: Forense Universitária, $2001 b$.

HALL, Stuart. Da diáspora: Identidades e mediações culturais. Org. Liv. Sovik; trad. Adelaine La Guardia Resende et al. Belo Horizonte: UFMG, 2003.

LACAN, Jacques. O estádio do espelho como formador da função do eu tal como nos é revelada na experiência psicanalítica. In: 1998. . Escritos. Rio de Janeiro: Jorge Zahar,

LINK, Daniel. O jogo dos cautos (sobre o policial). In: . Como se lê. Trad. Jorge H. Wolff. Chapecó: Argos, 2002.

PIGLIA, Ricardo. Una lectura de Cosas Concretas. Los Libros - un mes de publicaciones en Argentina y el mundo. n. 6. Buenos Aires, dez. 1969.

. Nueva narrativa norteamericana. Los Libros - un mes de publicaciones en

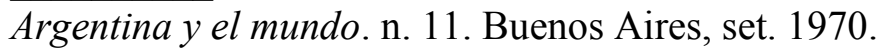

- Máo Tse-Tung. Práctica estética y lucha de clases. Los Libros. Para una crítica política de la cultura. n. 25. Buenos Aires, mar. 1972.

. Notas sobre Brecht. Los Libros. Para una crítica de la política de la cultura.

n. 40. Buenos Aires, mar.-abr. 1975. 
. Nome falso. Trad. Heloisa Jahn. São Paulo: Iluminuras, 1988.

. Sobre falsificações e outras histórias - Entrevista a Héctor Alimonda. Novos Estudos. n. 23. São Paulo: CEBRAP, mar. 1989.

Ficcíón y política en la literatura argentina. Revista Utopías del Sur. n. 6. Buenos Aires, mar. 1991. UFSC, ago-dez, 1996.

Ficção e Teoria: O escritor enquanto crítico Travessia. n.33, Florianópolis: Letras, 1998 .

Dinheiro queimado. Trad. Rosa Freire D’Aguiar. São Paulo: Companhia das

. Entrevista com Ricardo Piglia. Palavras ao Sul - seis escritores latinoamericanos contemporâneos. Belo Horizonte: Autêntica, 1999.

Formas breves. Trad. José Marcos Mariani de Macedo. São Paulo: Companhia das Letras, 2004.

. El arte es extrañamiento: la manera nueva de mirar lo que ya vimos Entrevista concedida a Juan Gabriel Vásques. Lateral. Disponível em: $<$ http://www.lateraled.es/revista/articulos/073piglia_jgvasques.html>. Acesso em 20 jul. 2005.

TSE-TUNG, Mao. Sobre a relação entre o conhecimento e a prática, entre o saber e o fazer. Disponível em: <http://www.comunismo.com.br>. Acesso em 28 jul. 2008.

WOLFF, Jorge H. Telquelismos latino-americanos: a teoria crítica francesa no entrelugar dos trópicos. Tese de Doutorado. Florianópolis: Curso de Pós-Graduação em Literatura da Universidade Federal de Santa Catarina, 2001. 